\title{
Pengaruh Persepsi terhadap Minat Memilih Baitul Maal Wat Tamwil (BMT) Insani Padangsidimpuan
}

\author{
Fadhlan Shubuhanda 1, Fatahuddin Aziz Siregar², Damri Batubara ${ }^{3}$ \\ 1,2Institut Agama Islam Negeri Padangsidimpuan \\ 1,2Jalan T. Rizal Nurdin Km. 4,5 Sihitang, Padangsidimpuan \\ Email: shubuhandafadhlan@gmail.com
}

\begin{abstract}
Abstrak
Masyarakat Lingkungan V Kelurahan Sidangkal Kecamatan Padangsidimpuan Selatan tergolong masyarakat yang majemuk dari segi agama yang dianut. Penelitian ini dilakukan untuk mengetahui apakah ada pengaruh persepsi terhadap minat memilih Baitul Maal wat Tamwil (BMT) Insani Padangsidimpuan, dan menganalisis kriteria seleksi yang dipertimbangkan dalam memilih BMT Insani Padangsidimpuan serta menganalisis sikap masyarakat. Teknik pengambilan sampel yang digunakan pada penelitian ini adalah sampling jenuh. Sampling Jenuh adalah teknik penentuan sampel bila semua anggota populasi digunakan sebagai sampel. Istilah lain sampel jenuh adalah sensus, dimana semua anggota populasi dijadikan sampel. Hasil penelitian menunjukkan adanya pengaruh persepsi terhadap minat memilih BMT Insani Padangsidimpuan, atau dari hasil output koefisien determinasi menunjukkan bahwa nilai $\mathrm{R}=0,564$ dan $\mathrm{R} \times \mathrm{R}=\mathrm{R}^{2}$ sebesar 0,318 yang menyatakan variabel $\mathrm{X}$ (Persepsi) menyumbang ke variabel Y (Minat) sebesar 31,8\%, artinya bahwa variabel $\mathrm{X}$ (Persepsi) dapat mempengaruhi variabel Y (Minat). Dan 68,2\% persepsi masyarakat dipengaruhi oleh faktor lain.
\end{abstract}

\section{Kata Kunci: Persepsi, Minat, dan Baitul Maal wat Tamwil (BMT).}

\section{Abstract}

Environmental Community $V$ Sidangkal Subdistrict, South Padangsidimpuan Subdistrict is classified as a pluralistic society in terms of religion. This research was conducted to determine whether there is an effect of perception on the interest in choosing Baitul Maal wat Tamwil (BMT) Insani Padangsidimpuan, and to analyze the selection criteria that were considered in selecting BMT Insani Padangsidimpuan and to analyze people's attitudes. The sampling technique used in this study was saturated sampling. Saturated Sampling is a sampling technique when all members of the population are used as samples. Another term saturated sample is census, where all members of the population are sampled. The results showed that there was an effect of perception on the interest in choosing $B M T$ Insani Padangsidimpuan, or from the results of the coefficient of determination showed that the value of $R=0.564$ and $R \times R=R 2$ was 0.318 which stated that the $X$ (Perception) variable contributed to the $Y$ (Interest) variable by 31, 8\%, meaning that the variable $X$ (Perception) can affect the variable Y (Interests). And 68.2\% of people's perceptions are influenced by other factors.

Keywords: Perception, Interests, and Baitul Maal wat Tamwil (BMT). 


\section{PENDAHULUAN}

Baitul Maal wat Tamwil (BMT), merupakan salah satu lembaga keuangan mikro non bank yang bersifat informal. Lembaga ini disebut informal karena keberadaan BMT tidak memerlukan legitimasi formal dari pemerintah/instansi terkait. Kinerja Baitul Maal wat Tamwil hampir sama dengan koperasi dimana di dalamnya terdapat pula berbagai produk baik untuk pengumpulan dana dari masyarakat maupun penyaluran dana kepada masyarakat (Andri Soemitra, 2009).

Baitul Maal wat Tamwil (BMT) merupakan salah satu alternatif lembaga keuangan Syari'ah. BMT memiliki fungsi utama seperti kegiatan Bank Syari'ah pada umumnya. BMT yang melaksanakan fungsinya sebagai lembaga keuangan Syari'ah dengan melakukan kegiatan penghimpunan dana masyarakat, melakukan penyaluran dana kepada masyarakat, dan juga memberikan jasa-jasa lainnya. Sehingga dapat menghasilkan laba yang maksimal untuk keperluan orang yang membutuhkan layanan jasa BMT tersebut (Syukri Iska, 2012).

BMT merupakan lembaga yang berhak untuk melakukan kegiatan ekonomi seperti perdagangan, industri, pertanian dan lain sebagainya untuk kemajuan ekonomi masyarakat kecil. Allah SWT sudah menganjurkan untuk berdagang serta menyalurkan hasil usaha tersebut kejalan yang benar sebagaimana firman Allah SWT dalam al-Qur'an surah al-baqarah ayat 267. Dari ayat di atas dijelaskan bahwa Allah SWT menganjurkan kita untuk berusaha dan menafkahkan sebagian dari hasil usaha kita dijalan yang benar, menyalurkannya untuk kepentingan umat, baik disalurkan langsung kepada yang membutuhkannya ataupun melalui lembaga yang terkait.

Baitul Maal wat Tamwil (BMT) Insani merupakan lembaga keuangan mikro yang berada di wilayah Kota Padangsidimpuan. Maju dan berkembangnya lembaga ini di masa yang akan datang tergantung kepada kemampuannya mengelola dan memenuhi kebutuhan anggotanya dalam pelaksanaan kegiatannya.

Menurut survei penulis dari status masyarakat Lingkungan V Kelurahan Sidangkal Kecamatan Padangsidimpuan Selatan, kebanyakan masyarakat perekonomiannya sederhana atau penghasilan rata-rata di bawah dan sebagian masyarakat tersebut kesehariannya adalah pedagang, berternak, dan petani, yang membutuhkan dana untuk mengembangkan usaha mereka. Maka dari itu, semakin besar peluang Baitul Maal wat Tamwil (BMT) Insani Padangsidimpuan untuk mempromosikan produknya, tetapi permasalahannya kebanyakan masyarakat sudah melekat pada konsep Lembaga Keuangan Kovensional.

Wawancara yang dilakukan dengan Bapak Ali Husin Nasution selaku Kepala Lingkungan V Kelurahan Sidangkal diperoleh bahwa dari \pm 283 Kartu Keluarga (KK) Lingkungan V Kelurahan Sidangkal Kecamatan Padangsidimpuan Selatan, yang mayoritaskan agama Islam. Persepsi masyarakat tentang Baitul Maal wat Tamwil (BMT) dari observasi 
sementara peneliti sangatlah beragam, mulai dari yang tidak tahu sama sekali, tahu, kurang tahu dan ada pula yang benar-benar paham tentang Baitul Maal wat Tamwil (BMT).

Alasan Bapak Sukirno bertransaksi di konvesional karena Bapak Sukirno beranggapan bahwa Syariah sama saja dengan Konvensional, dia beranggapan keduanya merupakan dua lembaga yang sama yang memberikan layanan yang sama, dan dia juga mengatakan Syariah dengan Konvensional sama saja, hanya saja yang membedakannya adalah nama.

Dan peneliti juga wawancarai Ibu Eka Rizky Mardhiati, dia mengatakan semua Lembaga Keuangan itu sama, baik itu Syariah atau Konvesioanl. Dan dia mengatakan bagi hasil dengan bunga itu tidak ada bedanya sama sekali, dan bertransaksi di konvensional lebih mudah dan tidak ribet.

Hal di atas juga bisa saja di sebabkan karena kurangnya pemahaman masyarakat tentang Syariah tersebut, baik dari segi bagi hasil, produk, dan proses transaksi. Hal ini seharusnya menjadi perhatian utama para praktisi untuk menjadikan masyarakat yang perekonomian sederhana atau penghasilan rata-rata di bawah, sebagai objek utama menunjang perkembangan Syariah khususnya di Lingkungan V Kelurahan Sidangkal Kecamatan Padangsidimpuan Selatan. Berdasarkan masalah di atas, maka peneliti memandang bahwa penelitian ini penting untuk dilakukan.

\section{KAJIAN TEORITIS}

Pada hakikatnya persepsi adalah suatu proses aktivitas seseorang dalam memberikan kesan, penilaian, pendapat, merasakan dan menginterprestasikan sesuatu berdasarkan informasi yang dipersepsi, sehingga dapat menerima dan menyerap informasi dari lingkungan sekitar (Dedy Mulyana, 2002). Ada beberapa faktor yang mempengaruhi persepsi, yaitu latar belakang pengetahuan dan pendidikan, usia, agama, dan pekerjaan (Hartono \& Arnicum Aziz, 1993).

Minat merupakan suatu kecenderungan untuk memberikan perhatian dan bertindak terhadap orang, aktivitas atau situasi yang menjadi objek dari minat tersebut dengan disertai perasaan senang (Abdul Rahman Shaleh dan Muhbib Abdul Wahab, 2004). Minat adalah kemauan hati seseorang untuk memiliki atau menggunakan suatu objek yang menyangkut dirinya dengan disertai perasaan senang tanpa ada paksaan dari orang lain. Faktor-faktor yang mempemgaruhi minat diantaranya; persepsi, keyakinan, dan sikap (Ujang Sumarwan, 2015).

Menurut Nurul Huda secara konseptual, Baitul Maal wat Tamwil (BMT) memiliki dua fungsi sebagai berikut (Nurul Huda dkk, 2012). 


\section{Baitul Maal Wat Tamwil (BMT)}

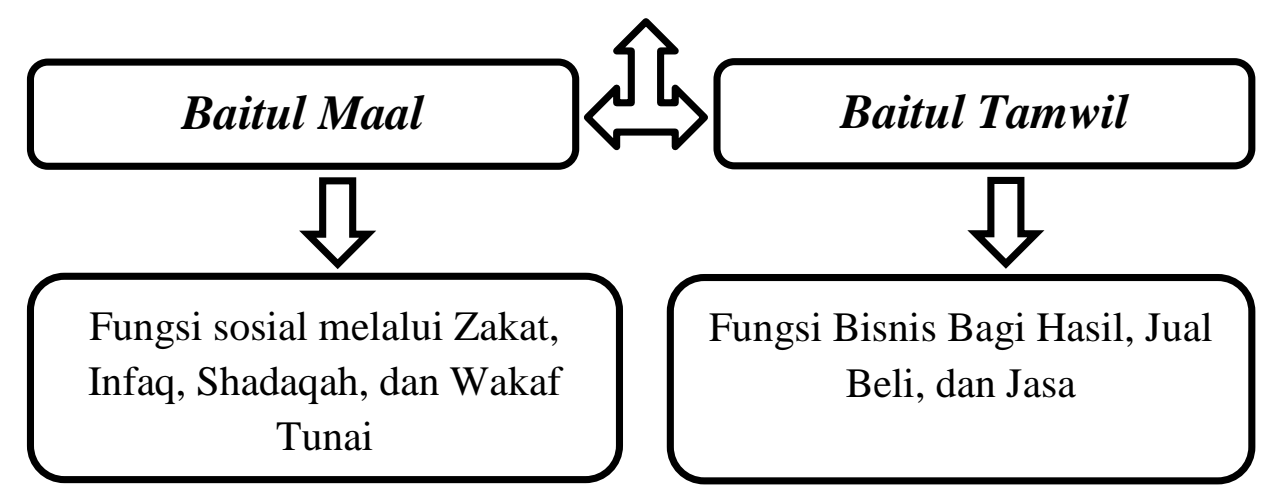

Gambar 1. Fungsi Baitul Maal wat Tamwil (BMT)

Baitul Maal wat Tamwil (BMT) merupakan lembaga yang terdiri dari dua istilah yaitu Baitul Maal dan Baitul Tamwil. Baitul Maal lebih mengarah pada usaha-usaha pengumpulan dan penyaluran dana yang non profit, seperti zakat, infak, sedekah, dan wakaf tunai. Adapun Baitul Tamwil sebagai usaha pengumpulan dan penyaluran dana komersial. Usaha-usaha tersebut menjadi bagian yang tidak terpisahkan dari Baitul Maal wat Tamwil (BMT) sebagai lembaga pendukung kegiatan ekonomi masyarakat kecil dengan berlandaskan islam. Lembaga ini didirikan untuk memfasilitasi masyarakat bawah yang tidak terjangkau oleh pelayan Bank Islam dan BPR Islam (Nurul Hudan dan Muhammad Heykal, 2010).

Sebagai salah satu lembaga perekonomian ummat, Baitul Maal wat Tamwil (BMT) memiliki beberapa tujuan, antara lain (Ahmad Rodoni dan Abdul Hamid, 20o8) yakni meningkatkan dan mengembangkan potensi ummat dalam program pengentasan kemiskinan, khususnya pengusaha kecil/lemah; memberikan sumbangan aktif terhadap upaya pemberdayaan dan kesejahteraan ummat; menciptakan sumber pembiayaan dan penyediaan modal bagi anggota dengan prinsip syariah; mendorong sikap hemat dan gemar menabung; menumbuhkan usaha-usaha yang produktif; membantu para pengusaha lemah untuk mendapatkan modal pinjaman dan membebaskan dari sistem riba; menjadi lembaga keuangan alternatif yang dapat menopang percepatan pertumbuhan ekonomi nasional dan meningkatkan kualitas dan kuantitas kegiatan usaha, di samping meningkatkan kesempatan kerja dan penghasilan ummat.

Untuk mendukung penelitian ini, ada beberapa penelitian terdahulu sebagaimana dalam tabel berikut: 


\section{Tabel 1}

\section{Penelitian Terdahulu}

\begin{tabular}{|c|c|c|c|}
\hline No & $\begin{array}{c}\text { Nama } \\
\text { peneliti }\end{array}$ & Judul Penelitian & Hasil Penelitian \\
\hline 1. & $\begin{array}{l}\text { Wiwin } \\
\text { Khasanah } \\
\text { (2015) }\end{array}$ & $\begin{array}{l}\text { Pengaruh Persepsi Mahasiswa UIN } \\
\text { Sunan Kalijaga tentang Perbankan } \\
\text { Syariah terhadap Minat Menabung } \\
\text { di Bank Syariah (Studi pada } \\
\text { mahasiswa Fakultas Ekonomi dan } \\
\text { Bisnis Islam) }\end{array}$ & $\begin{array}{l}\text { Persepsi mahasiswa tentang } \\
\text { perbankan syariah berpengaruh } \\
\text { secara positif dan signifikasi } \\
\text { terhadap minat menabung di Bank } \\
\text { Syariah Mandiri (BSM) }\end{array}$ \\
\hline 2. & $\begin{array}{l}\text { Ewa Ilyas } \\
\text { Zulkifli } \\
\text { (2014) }\end{array}$ & 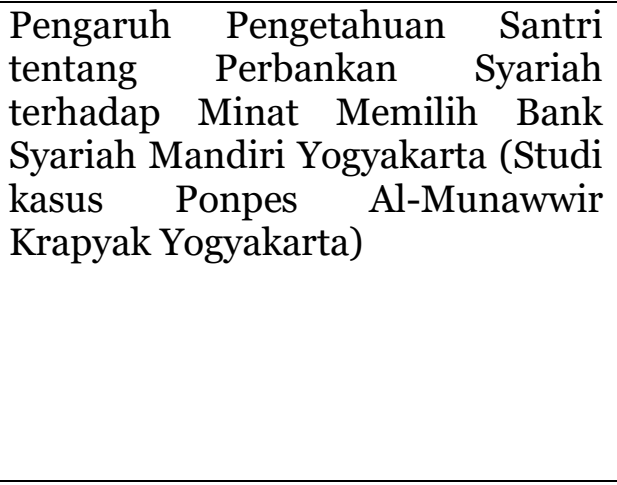 & $\begin{array}{l}\text { Hasil Uji } \mathrm{F} \text { menunjukan model } \\
\text { berpengaruh positif signifikasi, } \\
\text { yaitu minat santri dipengaruhi } \\
\text { secara bersama-sama oleh } \\
\text { pengatahuan defenisi, lokasi, } \\
\text { pronsip-prinsip dan produk- } \\
\text { produk perbankan syariah. } \\
\text { Sedangkan hasil uji persial, } \\
\text { variabel idenpenden berpengaruh } \\
\text { positif signifikasi terhadap minat } \\
\text { santri }\end{array}$ \\
\hline 3 . & $\begin{array}{l}\text { Masripah } \\
\text { Daulay } \\
\text { (2015) }\end{array}$ & $\begin{array}{lr}\text { Pengaruh } & \text { Pengetahuan } \\
\text { Masyarakat Kelurahan Pijorkoling } \\
\text { Kecamatan Padangsidimpuan } \\
\text { tentang Perbankan Syariah } \\
\text { terhadap Minat Menjadi Nasabah } \\
\text { di Bank Syariah. }\end{array}$ & $\begin{array}{l}\text { Pengetahuan masyarakat } \\
\text { terhadap Bank Syariah responden } \\
\text { hanya mengetahui tentang bunga } \\
\text { dan bagi hasil, sedangkan istilah- } \\
\text { istilah dalam Perbankan Syariah } \\
\text { seperti ijarah, mudharabah, dan } \\
\text { musyarakah masih belum } \\
\text { diketahui dan dimengerti sebagian } \\
\text { masyarakat. }\end{array}$ \\
\hline
\end{tabular}

Persamaan penelitian ini dengan saudari Wiwin Khasanah terletak pada variabel Y yaitu sama-sama meneliti tentang minat, sedangkan perbedaannya adalah terletak pada studi kasus penelitian, dimana studi kasus penelitian Wiwin Khasanah pada mahasiswa, dan penelitian ini studi kasus penelitian pada masyarakat.

Persamaan penelitian ini dengan Ewa Ilyas Zulkifli terletak pada variabel Y tentang minat, sedangkan perbedaannya terletak pada tempat penelitian, dimana tempat penelitian Ewa Ilyas Zulkifli pada Bank Syariah Mandiri Yogyakarta, dan penelitian ini tempat penelitiannya pada Baitul Maal wal Tamwil (BMT) Insani Padangsidimpuan.

Persamaan penelitian ini dengan Masripah Daulay terletak pada variabel Y tentang minat, sedangkan perbedaannya terletak masyarakat desa, dimana penelitian Masrifah Daulay pada masyarakat Kelurahan Pijor Koling Kecamatan Padangsidimpuan, sedangkan penelitian ini pada masyarakat Lingkungan V Kelurahan Sidangkal Kecamatan Padangsidimpun Selatan.

Kerangka pikir dapat disebut juga dengan istilah paradigma penelitian yang menggambarkan keterkaitan antara satu variabel dengan variabel lainnya dalam satu 
penelitian (Ahmad Nizar Rangkuti, 2014). Adapun kerangka pikir dalam penelitian ini sebagai berikut:

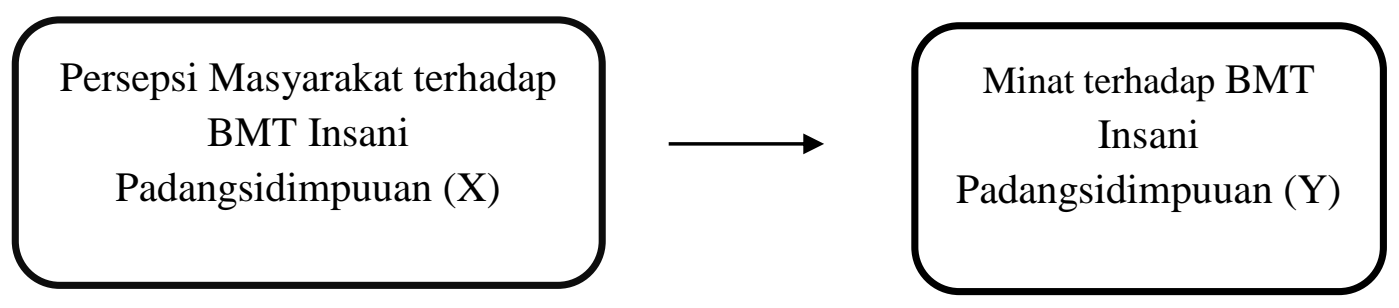

Gambar 2. Kerangka Pikir

Dari gambar di atas peneliti menggambarkan bahwa pengaruh persepsi terhadap minat memilih Baitul Maal wat Tamwil (BMT) Insani Padangsidimpuan dipengaruhi dua unsur yaitu: Persepsi masyarakat terhadap Baitul Maal wat Tamwil (BMT) Insani Padangsidimpuan; dan Minat masyarakat terhadap Baitul Maal wat Tamwil (BMT) Insani Padangsidimpuan.

\section{METODE PENELITIAN}

Penelitian ini dilakukan pada masyarakat Lingkungan V Kelurahan Sidangkal Kecamatan Padangsidimpuan Selatan. Jenis yang dipakai adalah penelitian kuantitatif. Kuantitatif adalah penelitian yang menggunakan data kuantitatif (data yang berbentuk angka atau data yang di angkakan), atau data yang diukur dalam suatu skala numeric (angka) (Mudrajat Kuncoro, 2009). Berdasarkan sumbernya, data yang diperoleh penelitian adalah data primer, yaitu data yang diperoleh penelitian langsung dari sumber asli. Dalam penelitian ini yang menjadi sumber aslinya adalah masyarakat Lingkungan V Kelurahan Sidangkal Kecamatan Padangsidimpuan Selatan, dan data sekunder juga digunakan pada penelitian ini untuk mengetahui jumlah seluruh masyarakat Lingkungan V Kelurahan Sidangkal Kecamatan Padangsidimpuan Selatan.

Di dalam suatu penelitian dibutuhkan populasi karena memiliki peranan yang begitu penting. Pengertian populasi adalah seluruh kumpulan dari elemen-elemen yang akan dibuat kesimpulan. Beberapa defenisi populasi menurut ahli yang menunjukkan keadaan dan jumlah objek penelitian secara keseluruhan yang memiliki karakteristik tertentu. Sebagai contoh seorang peneliti ingin melakukan penelitian mengenai perbedaan pendapatan petani di suatu lokasi. Objek penelitian yang menjadi populasi dalam penelitian ini adalah seluruh petani yang ada di lokasi tersebut. Populasi adalah serumpun atau sekolompok objek yang menjadi sasaran penelitian (Ahmad Nizar Rangkuti, 2014). Populasi penelitian ini adalah masyarakat Lingkungan V Kelurahan Sidangkal Kecamatan Padangsidimpuan Selatan yang sudah menjadi anggota Baitul Maal Wat Tamwil (BMT) Insani Padangsidimpuan yang berjumlah 22 orang/jiwa. JISFIM: Journal of Islamic Social Finance Management, Volume 1, No 1 Tahun 2020 http://jurnal.iain-padangsidimpuan.ac.id/index.php/JISFIM 
Sampel adalah suatu himpunan bagian (subset) dari unit populasi (Mudrajat Kuncoro, 2009). Jadi sampel adalah bagian dari jumlah dan karakteristik yang memiliki oleh populasi.

Teknik pengambilan sampel yang digunakan pada penelitian ini adalah sampling jenuh. Sampling Jenuh adalah teknik penentuan sampel bila semua anggota populasi digunakan sebagai sampel. Hal ini dilakukan bila jumlah populasi relatif kecil, kurang dari 30 orang. Istilah lain sampel jenuh adalah sensus, dimana semua anggota populasi dijadikan sampel (Sugoyono, 2012).

Data merupakan salah satu komponen riset, artinya tanpa data tidak akan ada riset. Data yang akan dipakai dalam riset haruslah data yang benar. Karena data yang salah akan menghasilkan informasi yang salah. Ada dua instrumen pengumpulan data yang digunakan dalam penelitian ini, yaitu angket (kuisioner) dan dokumentasi. Koesioner adalah teknik pengumpulan data yang dilakukan dengan memberi seperangkat pertanyaan atau pernyataan tertulis kepada responden untuk dijawab (Sugiyono, 2012).

Bentuk umum sebuah angket terdiri dari bagian pendahuluan berisikan petunjuk pengisian angket, bagian identitas responden seperti nama, alamat, umur, pekerjaan, jenis kelamin, status pribadi dan sebagianya, kemudian baru memasuki bagian isi angket (M. Burhan Bungin, 2005). Dari bentuk isi inilah kemudian angket dibedakan menjadi beberapa bentuk seperti angket terbuka, angket tertutup, dan angket campuran (Suharsimi Arikunto, 1998).

Angket terbuka adalah angket yang disajikan dalam bentuk sedemikian rupa sehingga responden dapat memberikan isian sesuai dengan kehendak dan keadaannya. Angket tertutup adalah angket yang disajikan sedemikian rupa sehingga responden tingga memberikan tanda centang $(\sqrt{ })$ pada kolom atau tempat yang sesuai. Angket campuran, yaitu gabungan antara angket terbuka dan angket tertutup.

Jadi, angket dalam penelitian ini adalah angket tertutup, sehingga respoden hanya memberikan tanda centang $(\sqrt{ })$ pada kolom yang disediakan. Untuk skala pengukuran data yang digunakan dalam penelitian ini adalah skala likert. Skala likert merupakan salah satu teknik pengukuran sikap yang paling sering digunakan dalam riset pemasaran. Dalam pembuatan skala likert, periset membuat beberapa pernyataan yang berhubungan dengan suatu isu atau objek, lalu objek atau responden diminta untuk mengidentifikasi tingkat kesetujuan atau ketidak setujuan mereka terdapat masing-masing pernyataan (Juliansyah Noor, 2011).

Instrumen ini akan menghasilkan total skor bagi tiap-tiap anggota sampel yang di wakili oleh setiap nilai skor seperti yang tercantum dalam skala likert di bawah ini. 
Tabel 2

Indikator Skor

\begin{tabular}{|c|l|c|}
\hline No & \multicolumn{1}{|c|}{ Indikator } & Skor \\
\hline 1 & Sangat Setuju (SS) & 5 \\
\hline 2 & Setuju (S) & 4 \\
\hline 3 & Kurang Setuju (KS) & 3 \\
\hline 4 & Tidak Setuju (TS) & 2 \\
\hline 5 & Sangat Tidak Setuju (STS) & 1 \\
\hline
\end{tabular}

Dengan menggunakan skala likert 5 poin, caranya dengan menghadapkan responden pada sejumlah pertanyaan dan kemudian diminta untuk memberikan jawaban atas masingmasing pertanyaan dengan cara menceklisnya $(\sqrt{ })$ diantara salah satu indikator. Adapun kisikisi untuk angket setiap variabel adalah sebagai berikut:

Tabel 3

Kisi-kisi Persepsi Masyarakat

\begin{tabular}{|c|l|c|}
\hline Variabel & \multicolumn{1}{|c|}{ Indikator } & $\begin{array}{c}\text { Nomor } \\
\text { Soal }\end{array}$ \\
\hline \multirow{2}{*}{ Persepsi } & a. Pengamatan & 1,2 \\
\cline { 2 - 3 } & b. Pandangan & 3,4 \\
\cline { 2 - 3 } & c. Pendapat & 5,6 \\
\hline
\end{tabular}

Tabel 4

Kisi-kisi Minat Masyarakat

\begin{tabular}{|c|l|c|}
\hline Variabel & \multicolumn{1}{|c|}{ Indikator } & $\begin{array}{c}\text { Nomor } \\
\text { Soal }\end{array}$ \\
\hline \multirow{2}{*}{ Minat } & a. Rasa Senang & 1,2 \\
\cline { 2 - 3 } & b. Ketertarikan & 3,4 \\
\cline { 2 - 3 } & c. Keinginan & 5,6 \\
\hline
\end{tabular}

Dokumentasi merupakan catatan peristiwa yang sudah berlalu, dokumentasi biasa berbentuk tulisan, gambar atau karya-karya monumental dari seseorang (Sugiyono, 2012). Dalam artian lain teknik dokumentasi adalah salah satu metode pengumpulan data kualitatif dengan melihat atau menganalisis dokumen-dokumen yang dibuat oleh objek sendiri atau oleh orang lain tentang subjek.

Dalam penelitian ini dokumentasi penelitian adalah berupa catatan tentang keadaan masyarakat Lingkungan V Keluruhan Sidangkal Kecamatan Padangsidimpuan Selatan, dari segi letak geografis, keadaan penduduk, mata pencarian, tingkat pendidikan dan keadaan keagamanya yang peneliti peroleh dari Kantor Lurah Kelurahan Sidangkal.

JISFIM: Journal of Islamic Social Finance Management, Volume 1, No 1 Tahun 2020 http://jurnal.iain-padangsidimpuan.ac.id/index.php/JISFIM 
Analisis data yang digunakan pada penelitian ini adalah dengan menggunakan rumus Regresi Sederhana. Regresi atau Peramalan adalah suatu proses memperkirakan secara sistematis tentang apa yang paling mungkin terjadi di masa yang akan datang berdasarkan informasi masa lalu dan sekarang dimiliki agar kesalahan dapat diperkecil. Jadi regresi mengemukakan tentang keinginan apa yang terjadi di masa depan untuk memberikan kontribusi menentukan keputusan yang terbaik. Di gunakan untuk memprediksi bagaimana perubahan bila nilai variabel idenpenden dinaikkan nilainya (Sugiyono, 2012). Metode ini dilakukan dengan alat bantu statistik yaitu menggunakan program SPSS (Statistical Product and Service Solutions) versi 23.0.

Persamaan regresi dirumuskan sebagai berikut (Morissan, 2012):

$$
\mathrm{Y}=\beta_{\mathrm{o}}+\beta \mathrm{X}+\mathrm{e}
$$

Dimana:

$\mathrm{Y}=$ (baca $\mathrm{Y}$ topi) subjek variabel terikat yang diproyeksikan

$\mathrm{X}=$ variabel bebas yang mempunyai nilai tertentu untuk diprediksikan

$\beta_{\mathrm{o}}=$ nilai konstanta harga $\mathrm{Y}$ jika $\mathrm{X}=\mathrm{o}$

$\beta=$ nilai arah sebagai penentu ramalan (prediksi) yang menunjukkan peningkatan (+) atau nilai penurunan (-) variabel.

$\mathrm{e}=$ Error

Penelitian ini menggunakan dua uji hipotesis, yaitu koofisien determinasi $\left(\mathrm{R}^{2}\right)$ dan uji signifikansi individual (uji t). Koefsien Determinasi $\left(R^{2}\right)$ pada intinya mengukur seberapa jauh kemampuan model dalam menerangkan variasi dependen. Nilai Koefsien Determinasi $\left(\mathrm{R}^{2}\right)$ adalah di antara nol dan satu. Nilai $\mathrm{R}^{2}$ yang kecil berarti kemampuan variabel-variabel independen dalam menjelaskan variasi variabel dependen sangat terbatas. Nilai yang mendekati satu berarti variabel-variabel independent memberikan hampir semua informasi yang dibutuhkan untuk memprediksi variasi variabel independent. Secara umum koefisien determinasi untuk data silang (crossection) relatif rendah karena adanya variasi yang besar antara masing-masing pengamatan, sedangkan data tuntun waktu (time series) biasanya mempunyai nilai koefisien determinasi yang tinggi. Untuk menjelaskan aplikasi dengan menggunakan program SPSS. Untuk mengetahui persentase besarnya perubahan variabel independent yang disebabkan oleh variabel dependen (Algifari, 2000). Koefisien determinasi ini di mana:

X: Persepsi tentang Baitul Maal wal Tamwil (BMT) Insani Padangsidimpuan.

Y: Minat terhadap Baitul Maal wal Tamwil (BMT) Insani Padangsidimpuan.

Uji t pada dasarnya menunjukkan seberapa jauh pengaruh satu variabel penjelas secara individual dalam menerangkan variasi variabel terikat (C. Trihendradi, 2013). Jika t hitung > darit tabel pada tingkat kesalahan tertentu misalnya $5 \%(0,05)$ maka terdapat pengaruh yang http://jurnal.iain-padangsidimpuan.ac.id/index.php/JISFIM 
53 I Pengaruh Persepsi Terhadap Minat Memilih Baitul Maal Wat Tamwil ( B M T) Insani Padangsidimpuan

signifikan antara variabel bebas yaitu $\mathrm{X}$ dengan variabel terikat yaitu $\mathrm{Y}$, begitu sebaliknya (Nur Asnawi dan Masyuri, 2011).

Ho: Tidak terdapat pengaruh signifikan antara variabel independen terhadap variabel dependen.

Ha: Terdapat pengaruh signifikan antara variabel independen terhadap variabel dependen.

\section{HASIL DAN PEMBAHASAN}

Lingkungan V Kelurahan Sidangkal tempat penelitian merupakan salah satu Lingkungan yang terdapat di kecamatan Padangsidimpuan Selatan. Lingkungan V merupakan lingkungan paling ujung di kelurahan Sidangkal, yang merupakan populasi penelitian penulis dalam menyusun skripsi ini. Untuk mengetahui Lingkungan V dari sudut geografisnya dapat di lihat dari batas-batasnya. Adapun batas-batas wilayah Lingkungan V sebagai berikut yaitu sebelah timur berbatasan dengan Lingkungan VII Kelurahan Ujung padang; sebelah barat berbatasan dengan Lingkungan IV Kelurahan Sidangkal; sebelah utara berbatasan dengan Lingkungn I Kelurahan Ujung padang; sebelah selatan berbatasan dengan Lingkungan VI Kelurahan Ujung padang.

Pada dasarnya setiap masyarakat memiliki karakteristik yang dapat dilakukan dengan melakukan penggolongan. Hal ini berguna bagi penulis dalam menentukan analisa pembahasan dan mendeskripsikan data-data yang dikumpulkan dilapangan penelitian, untuk mengetahui bagaimana profil penduduk Lingkungan V Kelurahan Sidangkal Kecamatan Padangsidimpuan Selatan dapat dilihat dari tabel berikut:

Tabel 5

\section{Jenis Agama Masyarakat Lingkungan V}

\begin{tabular}{|c|l|c|c|}
\hline No & \multicolumn{1}{|c|}{ Agama } & Jumlah & Persen (\%) \\
\hline 1 & Islam & 1180 & $97 \%$ \\
\hline 2 & Kristen & 34 & $3 \%$ \\
\hline & Total & 1214 & $100 \%$ \\
\hline
\end{tabular}

Sumber: Data Profil Masyarakat Lingkungan V di Kantor Lurah Kelurahan Sidangkal.

Dari tabel di atas dapat di lihat bahwa jenis agama masyarakat Lingkungan V ada 2 jenis agama yaitu, agama Islam yang memiliki 1180 jiwa atau 97\% dari populasi penelitian, sedangkan agama Kristen memiliki 34 jiwa atau 3\% dari populasi penelitian. 
Tabel 6

Data Profil Masyarakat Lingkungan V

\begin{tabular}{|c|c|c|c|c|}
\hline No & Umur/Tahun & Laki-laki & Perempuan & Jumlah \\
\hline 1 & $0-4$ & 45 & 67 & 112 \\
\hline 2 & $5-9$ & 43 & 62 & 105 \\
\hline 3 & $10-14$ & 38 & 48 & 86 \\
\hline 4 & $15-19$ & 45 & 42 & 87 \\
\hline 5 & $20-24$ & 65 & 69 & 134 \\
\hline 6 & $25-29$ & 55 & 61 & 116 \\
\hline 7 & $30-34$ & 69 & 71 & 140 \\
\hline 8 & 35-39 & 58 & 54 & 112 \\
\hline 9 & $40-44$ & 53 & 60 & 113 \\
\hline 10 & $45-49$ & 30 & 35 & 65 \\
\hline 11 & $50-54$ & 15 & 25 & 40 \\
\hline 12 & $55-59$ & 21 & 20 & 41 \\
\hline 13 & $60-64$ & 10 & 12 & 22 \\
\hline 14 & 65-69 & 9 & 10 & 19 \\
\hline 15 & $70-74$ & 5 & 7 & 12 \\
\hline 16 & 75 ke atas & 3 & 5 & 8 \\
\hline & Jumlah & 566 & 648 & 1214 \\
\hline
\end{tabular}

Sumber: Data Profil Masyarakat Lingkungan V di Kantor Lurah Kelurahan Sidangkal.

Dari tabel di atas dapat di lihat bahwa masyarakat Lingkungan V berjumlah 1214 jiwa, yang memiliki umur berbeda-beda. Jika di lihat dari jenis kelamin laki-laki berjumlah 566 jiwa dan perempuan berjumlah 648 jiwa.

Tabel 7

Jenis Pekerjaan Masyarakat Lingkungan V

\begin{tabular}{|c|l|c|c|}
\hline No & Jenis Pekerjaan & Jumlah & Persen (\%) \\
\hline 1 & Petani & 546 & $45 \%$ \\
\hline 2 & Padagang & 242 & $\mathbf{2 0 \%}$ \\
\hline 3 & Honor & 98 & $8 \%$ \\
\hline 4 & Buruh & 182 & $15 \%$ \\
\hline 5 & PNS & 121 & $10 \%$ \\
\hline 6 & Lain-lain & 25 & $\mathbf{2 \%}$ \\
\hline & Jumlah & 1.214 & $\mathbf{1 0 0 \%}$ \\
\hline
\end{tabular}

Sumber: Data Profil Masyarakat Lingkungan V di Kantor Lurah Kelurahan Sidangkal.

Dari tabel di atas dapat di lihat bahwa jenis pekerjaan/mata pencarian yang di geluti masyarakat Lingkungan V berbeda-beda. Dalam penelitian ini jumlah populasi berdasarkan jumlah penduduk di Lingkungan $\mathrm{V}$ yaitu 1214 jiwa. Jika di lihat dari jenis pekerjaan petani berjumlah 546 jiwa, pedagang berjumlah 242 jiwa, honor berjumlah 98 jiwa, buruh berjumlah 182 jiwa, PNS berjumlah 121 jiwa, dan lain-lain (tidak tetap) berjumlah 25 jiwa.

JISFIM: Journal of Islamic Social Finance Management, Volume 1, No 1 Tahun 2020 http://jurnal.iain-padangsidimpuan.ac.id/index.php/JISFIM 
Dari gambar 4.4 di bawah menyatakan, adanya struktur pemerintahan Lingkungan V Kelurah Sidangkal, yang mempunyai fungsinya masing-masing dari Lurah, Kepala Lingkungan, Alim Ulama, Cerdik Pandai, Hatobangon, dan BKM. Selain struktur di atas ada juga organisasi yang dinamakan Naposo Nauli Bulung (NNB) dan Pemuda Pancasila yang berpesertakan atau beranggotakan pemuda dan pemudi Lingkungan V.

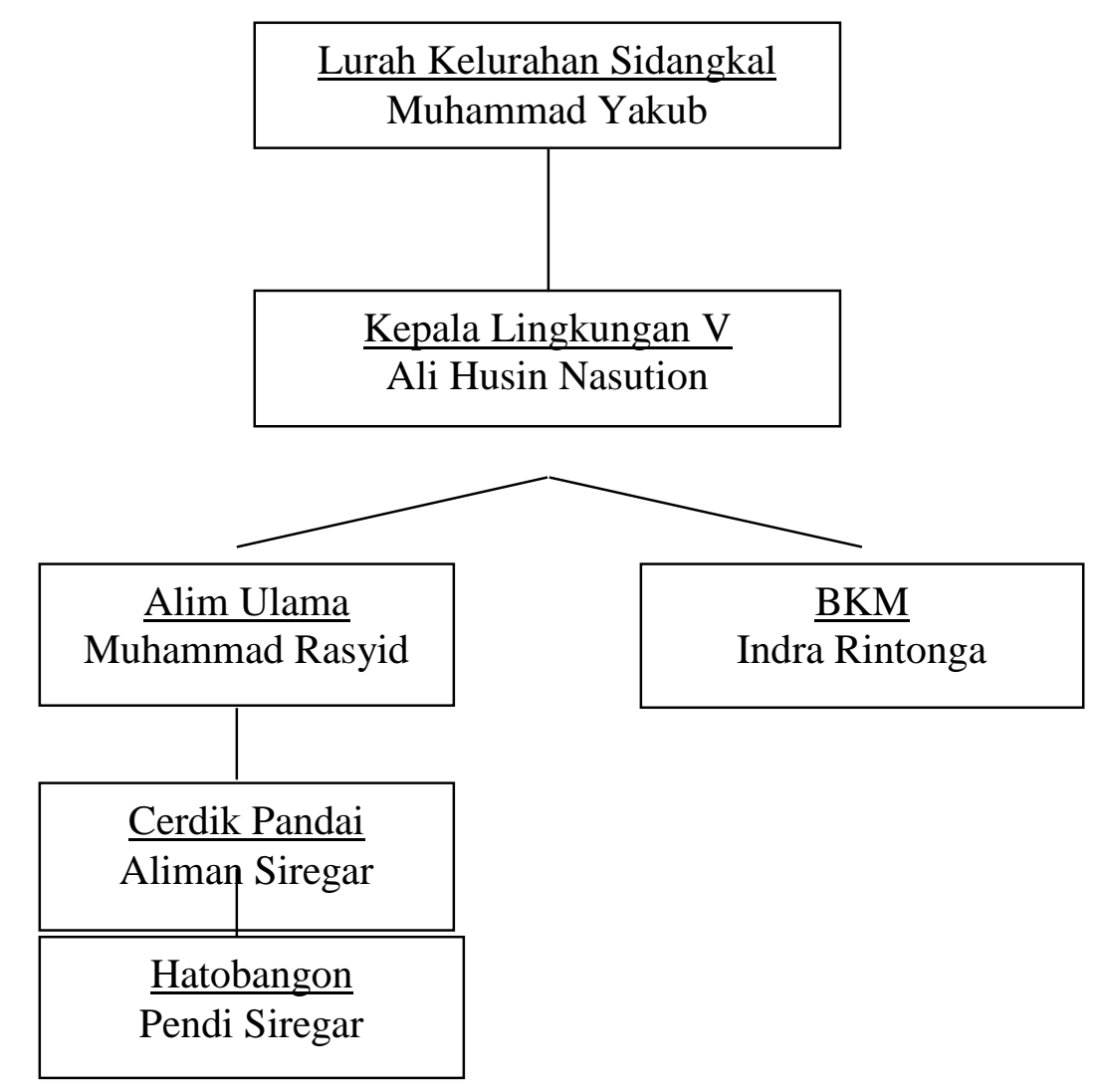

\section{Gambar 3. Struktur Pemerintahan Lingkungan V Kelurahan Sidangkal}

Uji validitas dan reabilitas dilakukan sebelum instrument digunakan dalam pengumpulan data instrument yang digunakan dalam penelitian ini adalah angket. Uji coba dilakukan kepada 22 responden sampel penelitian. Untuk mencari validitas (kesahihan) dan reabilitas (ketepatan).

Dari hasil perhitungan yang penulis lakukan, dapat disimpulkan bahwa dari 6 pertanyaan untuk variabel X (Persepsi) semuanya valid dan untuk pertanyaan variabel $\mathrm{Y}$ (Minat) semua juga valid dan layak digunakan dalam penelitian. Dari perhitungan $r_{x y}$ dikonsultasikan dengan $r_{\text {tabel }}$ product moment dengan taraf signifikan 0.05 t. jika nilai $r_{x y}>$ nilai toleran maka item yang diuji valid. Untuk memperjelas keterangan tersebut maka akan ditampilkan hasil nilai validitasnya pada tabel berikut: 
Tabel 8

Hasil Uji Validitas Persepsi

\begin{tabular}{|c|c|c|c|}
\hline $\begin{array}{c}\text { Nomor } \\
\text { item } \\
\text { pertanyaan }\end{array}$ & Correlations item & r Tabel & Interprestasi \\
\hline 1 & 0,583 & \multirow{6}{*}{$\begin{array}{c}\mathrm{Df}=(\mathrm{N}-2) \\
\mathrm{Df}=22-2 \\
\mathrm{Df}=20 \\
0,05=0,422\end{array}$} & Valid \\
\hline 2 & 0,568 & & Valid \\
\hline 3 & 0,637 & & Valid \\
\hline 4 & 0,643 & & Valid \\
\hline 5 & 0,570 & & Valid \\
\hline 6 & 0,772 & & Valid \\
\hline
\end{tabular}

Sumber: Hasil Output SPSS versi 23.0

Tabel 9

Hasil Uji Validitas Minat

\begin{tabular}{|c|c|c|c|}
\hline $\begin{array}{c}\text { Nomor } \\
\text { item } \\
\text { pertanyaan }\end{array}$ & Correlations item & r Tabel & Interprestasi \\
\hline 1 & 0,580 & \multirow{6}{*}{$\begin{array}{c}\mathrm{Df}=(\mathrm{N}-2) \\
\mathrm{Df}=22-2 \\
\mathrm{Df}=20 \\
0,05=0,422\end{array}$} & Valid \\
\hline 2 & 0,824 & & Valid \\
\hline 3 & 0,755 & & Valid \\
\hline 4 & 0,498 & & Valid \\
\hline 5 & 0,617 & & Valid \\
\hline 6 & 0,661 & & Valid \\
\hline
\end{tabular}

Sumber: Hasil Output SPSS versi 23.0

Dari tabel 4.5 dan 4.6 di atas dapat dilihat bahwa terdapat 6 pertanyaan semuanya valid untuk variabel $\mathrm{X}$ dan $\mathrm{Y}$ karena nilai koefisien korelasi lebih besar dari $\mathrm{r}$ tabel $(0,422)$.

Suatu variabel dapat dikatakan reabel apabila nilai cronbach's Alpha $>$ 0.60. nilai reliabilitas dapat dilihat pada tabel berikut:

Tabel 10

Hasil Uji Reliabilitas Persepsi

Reliability Statistics

\begin{tabular}{|c|c|}
\hline Cronbach's Alpha & N of Items \\
\hline 0,692 & 6 \\
\hline
\end{tabular}

Sumber: Hasil Output SPSS versi 23.0

Tabel 11

Hasil Uji Reliabilitas Minat

Reliability Statistics

Cronbach's Alpha

$\mathrm{N}$ of Items

JISFIM: Journal of Islamic Social Finance Management, Volume 1, No 1 Tahun 2020 http://jurnal.iain-padangsidimpuan.ac.id/index.php/JISFIM 
Sumber: Hasil Output SPSS versi 23.0

Dari tabel 4.7 dan 4.8 dapat dilihat nilai Cronbach's Alpha > 0.60. hasil uji reliabilitas variabel X (Pesepsi) dengan 6 pertanyaan di peroleh Cronbach's Alpha 0.692. Dan hasil uji reliabilitas variabel Y (Minat) dengan 6 pertanyaan di peroleh Cronbach's Alpha 0.704. Maka dapat disimpulkan bahwa variabel variabel tersebut valid dan reliabel untuk mengukur variabel X (Persepsi) dan variabel Y (Minat).

Regresi linear Sederahana berfungsi untuk melakukan indentifikasi pengaruh variabel X (Persepsi) terhadap variabel Y (Minat). Hasilnnya dapat dilihat pada output SPSS sebagai berikut:

\section{Tabel 12}

\section{Hasil Regresi Linear Sederhana}

\section{Coefficients $^{\mathbf{a}}$}

\begin{tabular}{|c|c|c|c|c|c|}
\hline \multirow[t]{2}{*}{ Model } & \multicolumn{2}{|c|}{$\begin{array}{l}\text { Unstandardized } \\
\text { Coefficients }\end{array}$} & $\begin{array}{c}\text { Standardized } \\
\text { Coefficients } \\
\end{array}$ & \multirow[t]{2}{*}{$\bar{T}$} & \multirow[t]{2}{*}{ Sig. } \\
\hline & B & Std. Error & Beta & & \\
\hline $\begin{array}{l}\text { (Constant) } \\
\text { PERSEPSI }\end{array}$ & $\begin{array}{r}13.604 \\
.682\end{array}$ & $\begin{array}{r}11.199 \\
.258\end{array}$ & .564 & $\begin{array}{r}1.215 \\
2.643\end{array}$ & $\begin{array}{l}.243 \\
.000\end{array}$ \\
\hline
\end{tabular}

a. Dependent Variable: MINAT

Sumber: Hasil Output SPSS versi 23.0

Dari tabel hasil output, analisis regresi linear sederhana pada tabel Unsatandrdized Coefficients kolom B menyatakan untuk nilai regresi dengan constanta $\mathrm{a}=13,604, \mathrm{~b}=0,682$. Maka persamaan analisis regresi linear sederhana dalam penelitian ini adalah:

$$
\begin{aligned}
& \mathrm{Y}=\beta_{\mathrm{o}}+\beta \mathrm{X}+\mathrm{e} \\
& \mathrm{Y}=13,604+0,682 \mathrm{X}
\end{aligned}
$$

Keterangan $: \mathrm{Y}=$ Minat Masyarakat

$$
\begin{aligned}
\beta_{\mathrm{o}} & =\text { Konstanta } \\
\beta & =\text { Koefisien Regresi } \\
\mathrm{X} & =\text { Persepsi } \\
\mathrm{e} & =\text { Nilai kesalahan/Error }
\end{aligned}
$$

Dari persamaan regresi dapat diartikan bahwa:

1. Konstanta sebesar 13,604 dengan parameter positif menunjukkan bahwa apabila persepsi dianggap konstan atau ditiadakan maka minat masyarakat sebesar 13,604 satuan.

2. Jika koefisien variabel dinaikan 1 satu satuan dengan syarat variabel lain adalah constan, maka variabelnya akan naik sebesar: 
$0,682+13,604$

$=14,286$. Maka kenaikannya, $14,286 \times 100 \%=14,3 \%$

Analisis regresi adalah salah satu jenis analisis parametrik yang dapat memberikan dasar untuk memprediksi serta menganalisis varian. Sedangkan tujuan analisis regresi secara umum adalah menentukan garis regresi berdasarkan nilai konstanta dan koefisien regresi yang dihasilkan, mencari korelasi bersama-sama antara variabel terikat dan menguji signifikan pengaruh antara variabel $\mathrm{X}$ dan variabel $\mathrm{Y}$.

Berikut ini hasil pengelohan data yang menggambarkan tingkat Koefisien Determinasi $\left(\mathrm{R}^{2}\right)$ pada penelitian ini, sebagai berikut:

Tabel 13

Hasil Koefisien Determinasi $\left(\mathbf{R}^{2}\right)$

\begin{tabular}{|l|r|r|r|r|}
\hline Model & R & R Square & $\begin{array}{c}\text { Adjusted R } \\
\text { Square }\end{array}$ & Std. Error of the Estimate \\
\hline 1 & $.564^{\mathrm{a}}$ & .318 & .272 & 2.09466 \\
\hline
\end{tabular}

Sumber: Hasil Output SPSS versi 23.0

Dari hasil output di atas tersebut memiliki nilai koefisien determinasi menunjukkan bahwa nilai $\mathrm{R}=0,564$, dan dibandingkan dengan $\mathrm{r}$ tabel dengan ketentuan $\mathrm{df}=(\mathrm{N}-2)$ maka diperoleh nilai $r$ tabel 0,422, yang menyatakan $r$ hitung $>r$ tabel atau 0,564 $>0,422$, yang menyatakan bahwa hipotesis diterima. Dan $\mathrm{R} \times \mathrm{R}=\mathrm{R}^{2}$ sebesar 0.318 yang menyatakan variabel X (Persepsi) menyumbang ke variabel Y (Minat) sebesar 31,8\%, artinya bahwa variabel X (Persepsi) dapat mempengaruhi variabel Y (Minat). Dan 68,2\% persepsi masyarakat dipengaruhi oleh faktor lain.

\section{Tabel 14}

\section{Uji signifikasi Individual (uji t)}

\section{Coefficients $^{\mathbf{a}}$}

\begin{tabular}{|c|c|c|c|c|c|}
\hline \multirow[t]{2}{*}{ Model } & \multicolumn{2}{|c|}{$\begin{array}{c}\text { Unstandardized } \\
\text { Coefficients }\end{array}$} & $\begin{array}{c}\text { Standardized } \\
\text { Coefficients }\end{array}$ & \multirow[t]{2}{*}{$\mathrm{T}$} & \multirow[t]{2}{*}{ Sig. } \\
\hline & $\mathrm{B}$ & Std. Error & Beta & & \\
\hline $\begin{array}{l}\text { (Constant) } \\
\text { PERSEPSI }\end{array}$ & $\begin{array}{r}13.604 \\
.682 \\
\end{array}$ & $\begin{array}{r}11.199 \\
.258 \\
\end{array}$ & .564 & $\begin{array}{r}1.215 \\
2.643 \\
\end{array}$ & $\begin{array}{l}.243 \\
.000 \\
\end{array}$ \\
\hline
\end{tabular}

a. Dependent Variable: MINAT

Sumber: Hasil Output SPSS versi 23.0

Uji statistik t pada dasarnya menunjukkan seberapa jauh pengaruh suatu variabel indenpenden (Persepsi) secara individual dalam menerangkan variasi variabel dependen 
59 Pengaruh Persepsi Terhadap Minat Memilih Baitul Maal Wat Tamwil ( B M T) Insani Padangsidimpuan

(Minat). Ketentuan jika t hitung $>\mathrm{t}$ tabel, maka Ho ditolak dan Ha diterima, jika $\mathrm{t}$ hitung $<\mathrm{t}$ tabel maka Ho diterima dan Ha ditolak.

Untuk t tabel ( $5 \%: 2=2.5 \%$ (untuk dua sisi)) dengan derajad kebebasan $(\mathrm{df})=\mathrm{n}-\mathrm{k}-$ 1 , dimana $\mathrm{n}=$ jumlah sampel dan $\mathrm{k}=$ jumlah variabel independen, $\mathrm{df}=22-1-1$. Dengan pengujian dua sisi (signifikasi $=0.025$ ), maka di peroleh $\mathrm{t}$ tabel sebesar 2,086.

Berdasarkan tabel hasil uji t tersebut dapat kita lihat dimana niai t hitung variabel $\mathrm{X}$ (Persepsi) lebih besar dari pada t tabel atau 2,643 > 2,086 dengan tingkat signifikan dibawah 0.05 yaitu o.ooo. dengan demikian di ambil kesimpulan bahwa Ho ditolak dan Ha diterima, artinya terdapat pengaruh positif dan signifikan antara variabel X (Persepsi) terhadap variabel Y (Minat).

Berdasarkan perhitungan dari hasil Koefisien Determinasi $\left(\mathrm{R}^{2}\right)$ dengan menggunakan uji $\mathrm{R}^{2}$ maka diperoleh adalah $\mathrm{R}=0,564$, dan dibandingkan dengan $\mathrm{r}$ tabel dengan ketentuan $\mathrm{df}=(\mathrm{N}-2)$ maka diperoleh nilai $\mathrm{r}$ tabel 0,422 , yang menyatakan $\mathrm{r}$ hitung $>\mathrm{r}$ tabel atau 0,564 $>0,422$, yang menyatakan bahwa hipotesis diterima. Dan $\mathrm{R} \times \mathrm{R}=\mathrm{R}^{2}$ sebesar 0.318 yang menyatakan variabel X (Persepsi) menyumbang ke variabel Y (Minat) sebesar 31,8\%, artinya bahwa variabel X (Persepsi) dapat mempengaruhi variabel Y (Minat). Dan 68,2\% persepsi masyarakat dipengaruhi oleh faktor lain.

Sedangkan hasil uji t bahwa variabel X (persepsi) menunjukkan bahwa t hitung $>\mathrm{t}$ tabel yaitu 2,643> 2,086.

Kesimpulan hasil uji t ternyata variabel $\mathrm{X}$ (persepsi) memiliki hubungan yang signifikan dan berpengaruh terhadap variabel Y (minat). Dari tabel di atas dapat ditarik kesimpulan bahwa dari kolom $t$, $t$ hitung sebesar 2,643 dengan $t$ tabel sebesar 2,086. Artinya bahwa t hitung > t tabel yaitu 2,643 > 2,086. Maka Ha diterima dan Ho ditolak. Artinya bahwa variabel X (persepsi) berpengaruh terhadap variabel Y (minat). Dan pada tabel coefficieni kolom sig variabel $\mathrm{X}$ (persepsi) sebesar 0.000 dengan taraf signifikan sebasar 5\%. Artinya bahwa sig < yaitu 0.000 < 0.05 . Maka diperoleh bahwa Ha diterima dan Ho ditolak. Artinya variabel X (persepsi) memiliki pengaruh yang signifikan terhadap variabel Y (minat).

Hasil penelitian ini sejalan dengan penelitian Wiwin Khasanah yang berjudul Pengaruh Persepsi Mahasiswa UIN Sunan Kalijaga tentang Perbankan Syariah terhadap Minat Menabung di Bank Syariah (Studi pada mahasiswa Fakultas Ekonomi dan Bisnis Islam). Yang pada hasil penelitiannya menunjukkan bahwa variabel persepsi berpengaruh siginifikan dan positif terhadap minat menabung di Bank Syariah.

Penelitian ini juga sejalan dengan penelitian Musripah Daulay yang berjudul Pengaruh Pengetahuan Masyarakat Kelurahan Pijorkoling Kecamatan Padangsidimpuan tentang Perbankan Syariah terhadap Minat Menjadi Nasabah di Bank Syariah. Yang pada hasil penelitiannya menunjukkan bahwa variabel pengetahuan berpengaruh signifikan terhadap minat menjadi nasabah di Bank Syariah.

JISFIM: Journal of Islamic Social Finance Management, Volume 1, No 1 Tahun 2020 http://jurnal.iain-padangsidimpuan.ac.id/index.php/JISFIM 
Persepsi akan mempengarahui minat masyarakat, ketika masyarakat memiliki persepsi atau pandangan yang lebih banyak, maka masyarakat akan lebih efisien dan lebih cepat dalam mengola informasi.

Persepsi memiliki hubungan positif dan pengaruh yang signifikan terhadap minat masyarakat, hal ini berarti bahwa apabila persepsi masyarakat tentang Baitul Maal wat Tamwil (BMT) semakin baik maka minat masyarakat akan meningkat. Sebaliknya apabila persepsi masyarakat tentang Baitul Maal wat Tamwil (BMT) buruk/rendah maka minat masyarakat akan menurun.

\section{KESIMPULAN}

Berdasarkan hasil penelitian di atas bahwa variabel $\mathrm{X}$ (persepsi) memberikan pengaruh yang signifikan terhadap variabel Y (minat). Hal tersebut dapat dilihat dari analisis regresi linear sederhana pada tabel Unsatandrdized Coefficients kolom B menyatakan untuk nilai regresi dengan constanta $\mathrm{a}=13,604, \mathrm{~b}=0,682$. Persamaan analisis regresi linear sederhana dalam penelitian ini adalah: $\mathrm{Y}=\mathrm{a}+\mathrm{bX}+\mathrm{e}$. Jika koefisien variabel dinaikan $1 \mathrm{satu}$ satuan dengan variabel lain adalah constan, maka variabelnya akan naik sebesar 0,682 + $13,604=14,286$. Maka kenaikannya, 14,286 x 100\% = 14,3\%. Dan dilihat dari uji hipotesis dimana koefisien determinasi yang memperoleh $\mathrm{R}=0,564$, dan dibandingkan dengan $\mathrm{r}$ tabel dengan ketentuan $\mathrm{df}=(\mathrm{N}-2)$ maka diperoleh nilai $\mathrm{r}$ tabel 0,422 , yang menyatakan $\mathrm{r}$ hitung $>$ $\mathrm{r}$ tabel atau 0,564 > 0,422, yang menyatakan bahwa hipotesis diterima. Dan $\mathrm{R} \times \mathrm{R}=\mathrm{R}^{2}$ sebesar 0.318 yang menyatakan variabel $\mathrm{X}$ (Persepsi) menyumbang ke variabel Y (Minat) sebesar $31,8 \%$, artinya bahwa variabel $\mathrm{X}$ (Persepsi) dapat mempengaruhi variabel Y (Minat). Dan $68,2 \%$ persepsi masyarakat dipengaruhi oleh faktor lain. Dan berdasarkan uji individual (ujit), uji tersebut diuji pada taraf signifikan $5 \%$ dengan membandingkan $t$ hitung dengan $\mathrm{t}$ tabel Hasil analisis data menunjukkan bahwa t hitung $>\mathrm{t}$ tabel atau 2,643 > 2,086. Hal ini menunjukkan Ho ditolak dan Ha diterima, maka terdapat pengaruh yang signifikan antar variabel. Dengan demikian terdapat pengaruh yang signifikan peranan variabel $\mathrm{X}$ (persepsi) terhadap perkembangan variabel Y (minat).

\section{DAFTAR PUSTAKA}

Abdul Rahman Shaleh dan Muhbib Abdul Wahab, Lembaga Keuangan Syariah, Psikologi Suatu Pengantar dalam Perspektif Islam, Jakarta: Kencana, 2004.

Ahmad Nizar Rangkuti, Metode Penelitian Pendidikan: Pendekatan Kuantitatif, Kualitatif, PTK dan Penelitian Pengembangan, Bandung: Cita Pustaka Media, 2014.

Ahmad Rodoni dan Abdul Hamid, Lembaga Keuangan Syari’ah, Jakarta: Zikrul Hakim, 2008.

Algifari, Analisis Regresi: Teori, Kasus, dan Solusi, Yogyakarta: BPFE UGM, 200.

JISFIM: Journal of Islamic Social Finance Management, Volume 1, No 1 Tahun 2020 http://jurnal.iain-padangsidimpuan.ac.id/index.php/JISFIM 
61 Pengaruh Persepsi Terhadap Minat Memilih Baitul Maal Wat Tamwil (B M T) Insani Padangsidimpuan

Andri soemitra, Bank dan Lembaga Keuangan Syari’ah, Edisi Pertama, Cetakan Ke-2, Jakarta: Kencana, 2009.

Dedy Mulyana, Ilmu Komunikasi, Bandung: Remaja Rosda Karya, 2002.

H. Hartono \& Arnicum Aziz, Ilmu Sosial Dasar, Jakarta: Bumi Aksara, 1993.

Juliansyah Noor, Metodologi Penelitian : Tesis Disertasi, dan Karya Ilmiah, Jakarta: Kencana Paranada Media Group, 2011.

Mudrajat Kuncono, Metode Riset Untuk Bisnis dan Ekonomi, Jakarta: Erlangga, 2009.

M. Burhan Bungin, Metodologi Penelitian Kuantitatif, Jakarta: Kencana, 2005.

Nurul Huda dkk, Keuangan Publik Islam Pendekatan Teoritis dan Sejarah, Jakarta: Kencana, 2012.

Nurul Hudan dan Muhammad Heykal, Lembaga Keuangan Islam: Tinjauan Teoritis dan Praktis, Jakarta: Kencana, 2010.

Nur Asnawi dan Masyuri, Metodologi Riset Manajemen Pemasaran, Malang: UIN Maliki Press, 2011.

Sugiyono, Metode Penelitian Bisnis, Bandung: Alfabeta, 2012.

Suharsimi Arikunto, Prosedur Penelitian, Jakarta: PT. Rineka Cipta, 1998.

Syukri Iska, Sistem Perbankan Syari'ah di Indonesia, Yogyakarta: Fajar Media Press, 2012.

Ujang Sumarwan, Perliaku Konsumen Teori dan Penerapan dalam Pemasaran, Bogor: Ghalia Indonesia, 2015.

JISFIM: Journal of Islamic Social Finance Management, Volume 1, No 1 Tahun 2020

http://jurnal.iain-padangsidimpuan.ac.id/index.php/JISFIM 